\title{
APPROPRIATE USE OF ORAL ANTIHYPERTENSIVE DRUGS EVALUATION IN NONDIALYSIS CHRONIC KIDNEY DISEASE PATIENT OF PRIVATE HOSPITAL IN EAST BEKASI 2018-2020
}

\author{
Sukma Widayani ${ }^{1 *}$, Wahyu Nuraini Hasmar ${ }^{2}$ \\ 1. Department of Pharmacy, STIKes Mitra Keluarga, Bekasi-Indonesia \\ 2. Department of Pharmacy, STIKes Mitra Keluarga, Bekasi-Indonesia \\ *Correspondence: Sukma Widayani | STIKes Mitra Keluarga | sukmawedy0214@gmail.com
}

\begin{abstract}
Introduction: Chronic Kidney Disease (CKD) is currently one of the most common diseases and being a concern in the world, including in Indonesia. The number of patients with CKD tends to increase year by year. Hypertension is a cause and effect of CKD and contributes to its development. This study aimed to evaluate the appropriateness use of oral antihypertensive drugs in patients with chronic kidney disease of private hospital in East Bekasi for the 20182020 period.

Method: The method used in this study was observational data taken retrospectively from the medical records of nondialysis chronic kidney disease patients. The study population were all patients diagnosed with non-dialysis chronic kidney disease at the inpatient installation of private hospital in East Bekasi. The sample was taken by consecutive sampling method where the sample was determined based on the inclusion criteria of 50 patients.

Results: Evaluation of drug use in this study included right patient, right indication, right medication and right dose. The following results were obtained: right patient was $100 \%$, right indication was $98 \%$, right medication was $86 \%$ and right dose was $94.84 \%$.

Conclusion It can be concluded that evaluation of oral antihypertensive drugs usage in patients with chronic kidney disease need to be done so that the contribution of hypertension to CKD development decreases.
\end{abstract}

Keywords: Antihypertensive, Consecutive sampling, CKD, Evaluation, Hypertensive.

Received November 30, 2021; Accepted December 30, 2021

\section{INTRODUCTION}

Chronic Kidney Disease (CKD) is a chronic disease that progressively damages the kidneys so that fluid and electrolyte balance in the body is disrupted, having an impact on all systems of the body. CKD is currently becoming one of the diseases that a lot is happening and is a concern in the world, including in Indonesia. The World Health Organization (WHO) (2018) released data on the growth in the number of patients with chronic kidney disease in the world in 2015. 1.2 million people died of kidney failure in 2015, an increase of $32 \%$ since 2005 . The results of a survey conducted by the Society of Nephrology Indonesia (PERNEFRI) in 2014 estimated that about $12.5 \%$ of the population, or 25 million people, have experienced a decline in renal function. According to Dani (2015), the number of patients with kidney failure in Indonesia is around 150 thousand, with around 10 thousand undergoing hemodialysis. While the prevalence of chronic kidney disease in West Java is still high enough as a sufferer of kidney failure in Indonesia, with the diagnosis of most, namely renal failure terminal or ESRD, as much as 13\%. In the year 2014, according to PERNEFRI (2014), the causes of kidney damage were mainly hypertension, with a percentage of $37 \%$, and increased to $44 \%$ in 2015. Based on data from the IRR in 2018, concomitant diseases of patients with chronic kidney disease are the largest hypertensive diseases with a percentage of 51\%. According to Pugh (2019), hypertension is both a cause and a result of CKD and contributes to its development. Hypertension affects $30 \%$ of the adult population, and $90 \%$ of them have CKD. When eGFR decreases, the incidence and severity of hypertension increase. From the perspective of therapy, losing BP can slow the decline in eGFR, delay the development of ESRD, and reduce the incidence of CVD. Antihypertensive therapy may be used in patients with chronic kidney disease for other purposes. In addition to lowering blood pressure, antihypertensive therapy may also slow the progression of kidney disease in patients with or without hypertension (Pugh, 2019). Evaluation of the accuracy of the use of the drug is carried out by way of analyzing from the aspect of qualitative or quantitative. Research on the evaluation of the accuracy of the use of the drug has been done in several hospitals in Indonesia. Research conducted by the Tuloli (2019) di 
RSUD Toto Kabila shows the results of the evaluation according to the criteria of appropriate patients at $100 \%$, the right drug at $86,05 \%$, the exact indication at $83,72 \%$, and the right dose at $53,49 \%$. This is different from the research conducted by the Announcement (2019), which shows that the exact indication is $100 \%$; the right patient is $91,82 \%$; the right drug is $88,85 \%$; and the right dose is $98,14 \%$. Based on this background, it is necessary to evaluate the accuracy of the use of antihypertensive drugs in patients with chronic kidney disease, taking into account the right patient, the right indication, the right drug, and the right dose.

\section{METHOD}

This research is non-experimental and observational. This study was conducted retrospectively on patients with chronic kidney disease (CKD) in a private hospital in East Jakarta from February until March 2021. The population in this study were patients diagnosed with chronic kidney disease who were undergoing hospitalization. The sample in this study consists of 90 patients diagnosed as having chronic kidney disease who met the criteria for inclusion and exclusion. Patients with chronic kidney disease who were not on dialysis and had a minimum age of 18 years, were male or female, were receiving antihypertensive therapy, and had data in their medical records that included a history of the disease, data on drug therapy, blood pressure data, weight, and serum creatinine or GFR value. With medical record data that is not complete are excluded in this study.

The sampling technique used is non-probability sampling with consecutive sampling, which means that the sample taken is the whole subject of the observation and meets the criteria for the selection of the sample, which is then included in the sample to ensure the large samples required are met (Satroasmoro, 2011). The variables in this study were patients with chronic kidney disease without dialysis and medical record data. This study was conducted after obtaining permission from the hospital, and then recording the data from medical records in the space of the hospital's medical records. The data obtained from the medical record includes the data of patients with chronic kidney disease, namely, the patient's name, age, gender, body weight, concomitant diseases, and use of antihypertensive therapy, which is then analyzed descriptively.

The criteria used in assessing the accuracy of the drug include the right patient, the right indication, the right drug and the right dose. The use of the drug is precisely that of the patient when the decision maker considers the state of the patient so as not to cause contraindications to the individual patient (Commands, 2019). Appropriate indications of whether the patient was given the drug for accuracy in deciding on the administration of drugs based on medical reasons (Moh, 2011). Evaluation of the Accuracy of the Indications as to whether the patients were given antihypertensive drugs based on the value of blood pressure. It is said it is not appropriate if the patient experiences hypotension or BP $90 / 60 \mathrm{mmHg}$ (Kudo, 2017).

Evaluation of the accuracy of the drug is assessed based on the suitability of the selection of drugs to consider the diagnosis that has been written (Commands, 2019). The decision on the selection of drugs with a view to the treatment of therapy CKD with hypertension Administration of excessive doses, especially for drugs that have a narrow therapeutic index, is prohibited. Administration of the dose is too small to guarantee the achievement of the pharmacological effects of the optimal (Moh, 2011). The accuracy of the dose is assessed by varying the value of GFR or the value of serum creatinine. Evaluation of the accuracy is performed by comparing aspects of the use of antihypertensive drugs in the field with the criteria for their use that have been set by the Management of CKD, The Renal Drug Handbook, Medscape.com, and Guidelines JNC VII \& VIII, and presented in the form of a percentage.

\section{RESULTS}

Based on the research, the following results were obtained:

Table 1. Characteristics of Patients by Gender

\begin{tabular}{ccc}
\hline Gender & Medical Record & Percentage \\
\hline Women & 16 & $32 \%$ \\
Men & 34 & $68 \%$ \\
\hline Total & $\mathbf{5 0}$ & $\mathbf{1 0 0 \%}$ \\
\hline
\end{tabular}


Table 1 shows that of the 50 medical records of chronic kidney disease patients who used hypertension therapy, most of them were male, with 34 (68\%), while for female patients there were 16 medical records $(32 \%)$

Table 2. The Characteristics of the Patients Based On Age

\begin{tabular}{ccc}
\hline Age group & Medical Record & Percentage \\
\hline$<45$ & 17 & $34 \%$ \\
$46-59$ & 25 & $50 \%$ \\
$\geq 60$ & 8 & $16 \%$ \\
\hline Total & $\mathbf{5 0}$ & $\mathbf{1 0 0 \%}$ \\
\hline
\end{tabular}

The age of the patients in this study was categorized into 3 age groups referring to the age division by WHO, namely: adults <45 years, middle age (middle age) 45-60 years, and elderly > 60 years. Table 5.2 describes the number of medical records for each age group.

Table 3. The Characteristics of the Patients Based On Comorbidities

\begin{tabular}{ccc}
\hline Comorbidities & Case & Percentage (\%) \\
\hline CKD, Anaemia & 4 & 8 \\
CKD, Ascities (Fluit in peritoneal cavity) & 1 & 2 \\
CKD, Atherosclerotic Heart Disease & 1 & 2 \\
CKD, Chronic Hepatic Failure & 1 & 2 \\
CKD, Congestive Heart Failure & 2 & 4 \\
CKD, Constipation & 1 & 2 \\
CKD, Effusion Pleura & 1 & 2 \\
CKD, Essential (Primary) Hypertension & 12 & 24 \\
CKD, Fever & 1 & 2 \\
CKD, Gatritis & 1 & 2 \\
CKD, Heart Failure & 1 & 2 \\
CKD, Hypertensive Heart Disease Without (congestive) Heart & 1 & 2 \\
CKD, NIDDM without complications & 14 & 28 \\
CKD, Observation For Other Suspected Diseases and Conditions & 1 & 2 \\
CKD, Pneumonia & 1 & 2 \\
CKD, Septicaemia & 3 & 6 \\
CKD, UTI & 1 & 6 \\
Without comorbid & 3 & 100 \\
\hline Total & 50 & \\
\hline
\end{tabular}

In this study, comorbidities were diseases that appeared before, concurrently, or after the patient had chronic kidney disease and used oral antihypertensive therapy.

Table 4. Profile of Use Oral Antihypertensive Drugs,

\begin{tabular}{llc}
\hline \multicolumn{1}{c}{ The drug's usage } & \multicolumn{1}{c}{ Classes of drugs } & Total \\
\hline Single & ARB & 3 \\
& CCB & 7 \\
\multirow{5}{*}{ Combinations } & ACEi & 1 \\
& CCB + ARB & 7 \\
& CCB + Adrenergic inhibitors & 1 \\
& CCB + ACEi & 1 \\
& ARB + Diuretic & 1 \\
& CCB + Diuretic & 1 \\
& CCB + ARB + Diuretic & 6 \\
& CCB + ARB + Adrenergic Inhibitors & 5 \\
& CCB + ARB Combinations & 4 \\
& CCB + Diuretic + Adrenergic Inhibitors & 3
\end{tabular}




\begin{tabular}{ll}
$\mathrm{CCB}+\mathrm{ARB}+\mathrm{ACEi}+$ Adrenergic Inhibitors & 1 \\
$\mathrm{CCB}+\mathrm{ACEi}+$ Adrenergic Inhibitors & 2 \\
$\mathrm{CCB}+$ Diuretic + ARB + ACEi & 1 \\
CCB + ARB + Diuretic + Adrenergic Inhibitors & 4 \\
$\mathrm{CCB}+$ ARB + Diuretic + Adrenergic Inhibitors + ACEi & 1 \\
\hline
\end{tabular}

There are various kinds of oral antihypertensive drugs that are prescribed to patients with chronic kidney disease at private hospitals, either alone or in combination therapy. Of the several classes of antihypertensives, the five most prescribed classes are CCB, ARB, ACEi, Loop diuretics, and beta-blockers. The table above describes the profile of the use of oral antihypertensive drugs in patients with chronic kidney disease.

Table 5. Evaluation of Appropriate Use of Drugs

\begin{tabular}{ccc}
\hline Parameter & \% Accuracy & \% Inaccuracy \\
\hline Right Patient & 100 & 0 \\
Right Indication & 98 & 2 \\
Right Medication & 86 & 14 \\
Right Dose & 94,84 & 5,16 \\
\hline
\end{tabular}

Evaluation of accuracy is carried out by comparing aspects of the use of antihypertensive drugs in patients with chronic kidney disease with the criteria for use that have been set by the Renal Drug Handbook, 5th edition, JNC Guidelines VII and VIII, and Management of Chronic Kidney Disease.

\section{DISCUSSION}

Based on this study, it can be seen that there were 90 patients with non-dialysis chronic kidney failure at private hospitals in the city of Bekasi from 2018 to 2020. There were 50 patients who met the inclusion criteria, and 40 patients who were included in the exclusion criteria, including chronic kidney disease patients who did not receive oral antihypertensive therapy and did not have clinical data in the form of blood pressure. The study was carried out from February 9 to March 2, 2021 in the medical records section at a private hospital in East Bekasi.

\section{Data On Patient Characteristics}

Data collection characteristics of the patient aims to find out the identity of the patient as well as to know the profile of the use of the drug by the patient with chronic kidney disease nondialisis in inpatient private hospitals in the City of Bekasi in general. description of the characteristics of the patient, which includes gender, age, and concomitant diseases, based on the research that has been done. The characteristics of patients who are first will be discussed based on gender. Gender is one of the risk factors for the occurrence of chronic renal failure, especially male gender. It is mentioned in the research by Anita (2020) that the urinary tract of the male is long so that the barriers to the expenditure of urine from the bladder are high. These barriers can be in the form of a narrowing of the channel (stricture) or blockage of the duct by a stone.

Based on the data obtained in table 5.1, there were 34 patients gender male $(68 \%)$ and 16 patients female gender $(32 \%)$. This result is in line with research conducted by Husna (2019) in RS PKU Muhammadiyah Gamping Yogyakarta showed that male patients were more suffer from chronic kidney disease with the results of the 62 patients with male sex $(63.92 \%)$ and a total of 35 patients of the female gender (26.46\%). It is the same also with the research conducted by Nur et al (2015) Rsup Prof. Dr. R. D. Kandou Manado results showed that a total of 28 patients were male gender (52.8\%) and 25 patients of the female gender $(47.2 \%)$. While the data obtained by the National Health Service in the Uk showed that female patients $(10.6 \%)$ more than male patients $(5.8 \%)$ in adulthood. Based on data from previous research it was concluded that male gender is a lot of suffering from chronic kidney disease than the female gender.

Based on Table 5.2, characteristics of age showed that in the age range of adults older than 60 years, patients with chronic kidney disease have more than in other age groups. i.e. by $50 \%$. While patients with an age range from 18 to 45 years old, as much as 34\%, and those older than 60 years old, as much as $16 \%$. Age is one of the risk factors that predisposes to chronic kidney disease. At a young age, kidney failure can 
occur due to dehydration and chronic substance nefrotoksis. The consumption of food or beverages containing nephrotoxic substances will accelerate the destruction of the cells of the kidney. Research conducted by Jonathan (2015) found that the age group of patients with chronic kidney disease is aged 56 to 65 years, as of $28.3 \%$. This is in line with research by Ndraha (2018) that shows older adults suffer from chronic kidney disease at a rate of $62,45 \%$. The results of this study are in accordance with the theory that kidney function will decline progressively from the age of 40 years. At the age of 60 years, the ability of the kidneys to function at $50 \%$ of their capacity. It is caused by the physiologic reduction of the population of the nephron and the absence of the ability to regenerate anatomically (Anita, 2016). As a result, adults aged 25-64 years old have the highest prevalence of chronic kidney disease when compared to other age groups.

Chronic kidney disease can be caused by several diseases, such as hypertension. Hypertension is a cause and consequence of chronic kidney disease, meaning that hypertension can cause chronic kidney disease. This can happen because the damage is progressive due to the high pressure in the glomerulus. This causes the blood to flow towards the functional unit of the kidneys, which becomes impaired. Based on table 5.3, kidney disease is caused by hypertension by as much as $24 \%$. Diabetes mellitus is a major cause of renal failure in hospitals, with a percentage of $28 \%$. Previous research conducted by Tuloli (2019) showed that the concomitant diseases most patients suffered from CKD were hypertension (as much as 32,56\%) and diabetes mellitus (as much as 18,61\%). Diabetes mellitus is a group of metabolic diseases with the characteristic disease of hyperglycemia that occurs due to abnormalities in insulin secretion, impaired insulin action, or both, which cause a variety of chronic complications in the eyes, kidneys, nerves, and blood vessels (Rivandi, 2015).

Furthermore, concomitant diseases that cause the most pain are heart disease, among others. Atherosclerotic Heart Disease (1), Congestive Heart Failure (2), Heart Failure (1), Hypertensive Heart Disease Without (congestive) Heart (1). Congestive heart failure plays a role in mortality and morbidity, as well as worsening the patient's quality of life. Most patients with CKD have decreased diuresis (low diuresis) that can trigger fluid retention. Abnormalities in the structure and function of the left ventricle are common in patients with CKD. Heart disease coroner at the CKD also aggravates this condition, which plays a role in ischemia, damage to the cells of the myocardium, and fibrosis. Sepsis is a systemic inflammatory response to infection in the blood stream, which can be caused by pathogens such as bacteria, viruses, or fungi. Chronic heart failure $(\mathrm{CHF})$ can be a risk factor for decreasing the performance of the kidney in the control of balance in the body. CHF is a condition where the heart works less efficiently (heart failure) and is accompanied by blockage of the various organs of the body (Yusman, 2020).

Because of the abnormality of the pulmonary and decreased immune cellular and humoral defenses, as well as a disturbance in the function of phagocytic cells, the incidence of pulmonary infection is higher in patients with CKD undergoing hemodialysis. On CKD, the number of B lymphocytes and the ability to produce immunoglobulin, which is an abnormality of the immune humoral due to uremia. Uremia-related changes in the body's defense mechanisms of the host, thereby increasing bacterial infection (Febriana, 2015). Pneumonia occurs in patients with chronic kidney disease when the number of patients is 1 . Other infections that occur are UTIs (Urinary Tract Infections) or urinary tract infections. It occurs because patients with chronic kidney disease have immunity so low that they tend to be more prone to infections such as pneumonia, UTI, and sepsis (Sinaga, 2017).

Ascites occurs in patients with chronic kidney disease, with the number one patient. Ascites describes the condition of the collection of pathological fluid in the abdominal cavity. Although the pathogenesis of this condition is not yet known for certain, the theory mentioned hypoalbuminemia is one of the main factors in the occurrence of ascites in patients on dialysis (Yusman, 2020). Fluid buildup also occurs in the space of the pleura with patients amounted to 1 patient. Pleural effusion that appears on CKD Stadium 5 HD is almost always associated with the failure of the function of the kidneys and the heart, but the increased risk of infections such as tuberculosis or parapneumonia caused by immunosupresi in patients with CKD undergoing hemodialysis contribute as a cause of pleural effusion, especially in pleural effusion is exudative (Prastiwi, 2009).

The number of patients with anemia in this study is as high as four patients. Anemia commonly occurs in patients with chronic kidney disease, especially those undergoing hemodialysis. The amount of iron in the red blood cells lost during undergoing regular hemodialysis is between 1.5 and 2.0 grams every year. 
This amount is much greater than the iron that can be absorbed through food by the gastrointestinal tract (Garini, 2018). In previous research conducted by Kamaliah (2021) and Ndraha (2018), anemia was ranked 3 and 2 as concomitant diseases and complications of CKD, respectively. The researchers say that the cells of the peritubular that produce erythropoietin are partially damaged or completely destroyed along with the progression of the disease in the kidney. Sarwana, 2016). The production of erythropoietin is inadequate. This is due to progressive damage of the part of the kidneys that produce erythropoietin.

\section{The profile of hypertension drug use in CKD patients}

The class of antihypertensive drugs used in the treatment of chronic kidney disease nondialisis in hospitals is a group of ACEi, ARB, CCB, diuretics, and -Blockers. class of CCB (Calcium Chanal Blockers). Most widely used in this research, as many as $92 \%$ of patients get therapy with CCB, either alone or in combination with drugs from other groups. The treatment combination of antihypertensive drugs is a lot more effective compared to antihypertensive drugs alone. A single drug that is used the most is amlodipine, with a number of seven patients. Amlodipine itself is a drug class called CBB, or Calcium Chanal Blockers. Previous research conducted by Tuloli (2019) in the area of Gorontalo indicated that antihypertensive drugs are the most widely used class of CCB, with a single treatment of as much as $34,21 \%$, and the combination of CCB with other groups of as much as $36,85 \%$. This is in line with research by Husna (2019), that the drug class of CCB is the most widely used, with a percentage of as much as 28,14\%. CCB is effective for CKD and will be more effective if combined with ACEI, CCB dihydropyridine, and non-dihydropyridine, useful in the management of hypertension in CKD. Chronic Non-Proteinurik, either alone or in combination, can be used as first-line therapy in Chronic NonProteinurik.This proficiency level has been reflected in the ESC/ESH guidelines recently updated. The guidelines recommend combination therapy with an ACE inhibitor and CCB as first-line therapy in patients with proteinuria. In this risk group, the addition of amlodipine to the therapy of ACE inhibitors has a renoprotective effect in addition to the addition of a diuretic thiazide diuretic. Although generally well tolerated, CCB has the potential to aggravate peripheral edema, something that can be very troublesome for the patient (CKD) (Pugh, 2019).

Candesartan, irbesartan, and telmisartan are the ARB drug classes most commonly used in private hospitals in Bekasi Timur.In the research by Husna (2019), drug classes ARB and IRB were the most widely used, followed by candesartan and irbesartan. Meanwhile, according to Salwa (2013), the ARB drug class is the most commonly used with valasartan and irbesartan. In the JNC 7, it is said that the ARB is effective in slowing the progression of CKD compared to other antihypertensives. Neither is mentioned in the guide. ASH (American Society of Hypertension) showed that most patients with CKD should receive the ARB or ACEi in combination with a diuretic, and a lot of them require a diuretic loop rather than thiazide diuretics. In addition, if there is a conflict between the goals of slowing the development of the reduction of the risk of CKD and CVD, the decision-making of individuals is recommended based on risk stratification (Chobanian, 2003). Therapy of RAAS with angiotensin converting enzyme inhibitors (ACEi) or angiotensin receptor blockers (ARB) is recommended for patients with CKD to prevent or decrease the rate of progression to ESRD. ACEi or ARB should be the first-line agent for antihypertensive therapy for patients with CKD and is recommended for patients with albuminuria in spite of the need to control blood pressure. Both ACEi and ARB have the potential to slow the progression of kidney disease (Lukela et al., 2019).

\section{Evaluation of Appropriate Use of Drugs \\ Evaluation of Patient Appropriateness on Antihypertensive Use}

The accuracy of the patient is the accuracy of the selection of drugs that consider the state of the patient so as not to cause contraindications for the patient individually. Evaluation of the accuracy of the patient in the use of antihypertensive is done by comparing the contraindications or a history of drug allergy given with the condition of the patient according to the doctor's diagnosis. Individual responses to drug effects are very diverse. This is clearly seen in some types of drugs, such as Ramipril and Valsartan. In patients who are pregnant, nursing administration of the drug should be avoided. This study was conducted to see the patient's medical record and did not find a history of allergy to antihypertensive drugs. In this study, the results of the evaluation of the accuracy of the patient were $100 \%$ correct because the drug that was 
prescribed does not have contraindications for patients with chronic kidney disease who have concomitant diseases or those without concomitant diseases.

The results are in line with the research conducted by Salwa (2013) in the area of Surakarta and Husna (2019) in PKU Muhammadiyah Gamping Yogyakarta Hospital, which stated that the evaluation of the accuracy of the use of the drug seen from the criteria of appropriate patients is $100 \%$. While in the research conducted by Alaydrus (2019), the criteria for an appropriate patient was $96.67 \%$, where inaccuracy was found in 1 patient. It shows that in some hospitals in Indonesia, the evaluation of the accuracy of the use of the drug seen from the criteria of appropriate patients is good.

\section{Evaluation of Antihypertensive Indication Appropriateness}

Appropriate indication is defined as the selection of drugs based on the diagnosis and the administration of drugs in accordance with the symptoms felt by the patient. The selection and administration of drugs is based on medical grounds. Evaluation of the Accuracy of the Indications seen as to whether the patients were given antihypertensive drugs. It is said it is not appropriate if the patient experiences hypotension or BP $90 / 60 \mathrm{mmHg}$ (Kudo, 2017). In this study, the accuracy of the indications was $98 \%$ right, and $2 \%$ was not appropriate. said to be not appropriate because there was 1 patient who experienced hypotension who got antihypertensive therapy.

The goal of antihypertensive therapy in patients with chronic kidney disease is to control blood pressure so that it falls within the therapeutic targets set by the JNC 8, which are 140/90 $\mathrm{mmHg}$ for people under the age of 18 and $150 / 90 \mathrm{mmHg}$ for people over the age of 60.Such a result is not in line with the research tradition (2019) regarding the evaluation of the rationality of the use of antihypertensive drugs in the outpatient hospital of Dr. Soegiri Lamongan, with the results of the precise indication of $100 \%$. The inaccuracy obtained in this study is due to the patient's blood pressure being $87 / 56 \mathrm{mmHg}$ and receiving therapy for antihypertension, namely amlodipine group CCB. According to the information center of national medicine (pionas), amlodipine does not reduce myocardial contractility and does not cause deterioration in heart failure. This drug has a long working life. It happens to the patient because amlodipine has a working period that is longer than 24 hours, so that the effect of a decrease in blood pressure continues even if the blood pressure is normal.

\section{Evaluation of the Appropriate Use of Antihypertensive Drugs}

It is said to be proper use of the drug if the conformity of the provision of group therapy, either single or in combination, is considered with the diagnosis. The decision to perform therapeutic efforts is taken after the diagnosis is established correctly. Thus, the drug selected should have a therapeutic effect in accordance with the spectrum of the disease. Because the treatment is individualized to reflect that the effect of the drug is not the same for every individual, in this study, the evaluation of the accuracy of the use of hypertension drugs was $86 \%$ and was not appropriate as much as $14 \%$. This is in line with research conducted by Alydrus (2019), an evaluation of the accuracy of the use of medication that is equal to about $86.67 \%$ and research by Tradition (2019), an evaluation of the accuracy of the use of the drug that is equal to $96,67 \%$.

According to ASH (American Society of Hypertension) (2013), JNC 7 (2003), and Pharmacotherapy Handbook (2015), either a single drug or drug combination. The inappropriateness of the use of the drug is because there are 7 patients prescribed with amlodipine. It should be noted that inhibiting calcium channel dihydropyridine should not be prescribed without the use of ACEi or ARB simultaneously to patients with CKD because a single use can lead to hyperfiltration and albuminuria (Lukela et al., 2019). Of the antihypertensive agents, ACEi and ARB are very effective in slowing down disease progression in CKD diabetes and non-diabetes. If ACEi or ARB alone is not effective to control blood pressure, then calcium channel thiazide diuretics or dihydropyridine (for example, amlodipine) can be added.

According to the Pharmacotherapy Hanbook (2015), first-line therapy with the angiotensin converting enzyme inhibitor (ACEi) or angiotensin II receptor blocker (ARB) Add diuretic thiazide diuretics in combination with ARB if there is an additional reduction in proteinuria needed. Inhibiting the calcium channel, nondihidropiridin is commonly used as a remedy for antiproteinuria second line when ACEi or ARB is contraindicated or not tolerated (Wells et al., 2015). From the data of medical records in this study, it is seen that the patient has no contraindications or tolerance to the group of ACEi or ARB, then the class 
of CCB should not be given a single consideration, considering the side effects of hyperfiltration and albuminuria.

\section{Evaluation of Dosage Appropriateness Antihypertensive}

Dosage is the content of anything that can impact an organism biologically; the greater the amount, the greater the dose. The exact dosage that is appropriate in terms of frequency of administration, dose given, and route of administration of the drug to the patient. The accuracy of the dose was analyzed by comparing it with the Renal Drug Handbook and Management of Chronic Kidney Disease. When prescribing the dose of antihypertensive drugs, if the minimum dose and the dose per day are in the range of the minimum dose, then prescribing the right dose is recommended. In this study of 50 medical records, 155 antihypertensive drugs were prescribed. From the number 155 of drugs, 147 drugs do not require a dose adjustment and eight drugs require a dose adjustment. The drugs are captopril, ramipril, and bisoprolol.

According to the Management of Chronic Kidney Disease (2019), drug-drug captopril, ramipril, and bisoprolol require a dose adjustment using GFR data. They can be given to patients with chronic kidney disease. Then the accuracy of the dose of 155 of the drug is $94.84 \%$ for the exact dosage and $5.16 \%$ for the improper dose. The inaccuracy is due to the eight drugs' not adjusted doses. Of 147 drugs, dose adjustment for patients with chronic kidney disease accompanied by hypertension is no longer required for some drugs. Antihypertensive drugs are renoprotektif. This research is in line with previous research conducted by Husna (2019) in PKU Muhammadiyah Gamping Yogyakarta Hospital, which evaluated the accuracy of the dose at $91,72 \%$. Tuloli's (2019) research in the area of Gorontalo evaluation of the accuracy of the dose of 51,15\%

\section{CONCLUSION}

Based on the research that has been done regarding the evaluation of the use of antihypertensive drugs in patients with chronic kidney disease at a private hospital in East Bekasi in February and March 2021, it can be concluded that the evaluation of the use of oral antihypertensive drugs in chronic kidney disease is based on the patient's exact criteria of $100 \%$, based on the criteria for the right indication of $98 \%$, based on the criteria for the right drug by $86 \%$, and based on the criteria for the right dose of $94.84 \%$.

Based on the research that has been done, it is advisable to do further research on dose correction for patients with chronic kidney disease. It aims to improve the quality of patient health where the drugs prescribed are in accordance with the patient's physiological condition, which can reduce the risk of ESRD (End Stage Renal Disease) or end stage chronic kidney disease.

\section{REFERENCE}

Alaydrus, S., \& Toding, N. (2019). Pola Penggunaan Obat Hipertensi Pada Pasien Geriatri Di Rumah Sakit Anutapura Palu Periode 08 Juli-08 Agustus 2019. Jurnal Mandala Pharmacon Indonesia, 5(02), 6573. https://doi.org/10.35311/jmpi.v5i02.46

Anita, D. C. (2016). Status Nutrisi Pasien Gagal Ginjal Kronis Dengan Diabetes Mellitus Dan NonDiabetes Mellitus. Media Ilmu Kesehatan, 5(2), 92-98. https://doi.org/10.30989/mik.v5i2.56

Anita, D. C. (2020). Penilaian Status Gizi Pasien Gagal Ginjal Kronis Melalui Biokimiawi Darah. Universitas 'Aisyiyah Yogyakarta.

Armstrong, C. (2014). JNC 8 guidelines for the management of hypertension in adults. American Family Physician, 90(7), 503-504.

Ashley, C. A. D. (2019). The Renal Drug Handbook: The Ultimate Prescribing Guide for Renal Practitioners, 4th edition. In European Journal of Hospital Pharmacy (Vol. 5). https://doi.org/10.1136/ejhpharm-2016-000883

Brunton, L. L. J. S. L. K. L. P. (2006). The Pharmacological Basis of Therapeutics. In McGraw-Hill (Vol.7). https://doi.org/10.1016/bs.seda.2018.06.002

Charles, Lacy F, Lora L. Armstrong, Morton P. Goldman, L. L. L. (2009). Drug Information Handbook: Vol. edisi 17. Lexi-comp.

Chobanian, A. V., Bakris, G. L., Black, H. R., Cushman, W. C., Green, L. A., Izzo, J. L., Jones, D. W., Materson, B. J., Oparil, S., Wright, J. T., \& Roccella, E. J. (2003). Seventh report of the Joint National Committee on Prevention, Detection, Evaluation, and Treatment of High Blood Pressure. Hypertension, 42(6), 1206-1252. https://doi.org/10.1161/01.HYP.0000107251.49515.c2 Dani, R., 
Utami, G. T., \& Bayhakki. (2015). Hubungan Motivasi, Harapan, dan Dukungan Petugas

Kesehatan Terhadap Kepatuhan Pasien Gagal Ginjal Kronik Untuk Menjalani Hemodialisis. JOM, 2(2). https://doi.org/10.1007/s11139-020-00300-y

Depkes. (2017). InfoDATIN Pusat Data dan Informasi Kementerian Kesehatan RI: Situasi Penyakit Ginjal Kronis. 1-10. www.depkes.go.id/resources/download/pusdatin/infodatin/

Dipiro, J. T. (2005). Pharmacotherapy. In McGraw-Hill (Vol. 6). https://doi.org/10.1001/archinte.1980.00040020897004

Edmonston, D. L., \& Sparks, M. A. (2020). Therapeutic options for chronic kidney disease-associated pulmonary hypertension. Current Opinion in Nephrology and Hypertension, 29(5), 497-507. https://doi.org/10.1097/MNH.0000000000000624

Erwinanto, Santoso, A., Putranto, J. N., Tedjasukmana, P., Suryawan, R., Rifqi, S., \& Kasiman, S. (2015). Pedoman Tatalaksana Dislipidemia PERKI 2013. Indonesian Journal of Cardiology, 34(4), 245-270. https://doi.org/10.30701/ijc.v34i4.385

Fadhilah, A. Z. (2014). Chronic Kidney Disease Stage V. Definitions, 1(2), 110-113. https://doi.org/10.32388/yzopkc

Febriana, L. (2015). Hubungan Antara Kondisi Komorbid dan Mortalitas pada Pasien Gagal Ginjal Kronik yang Menjalani Hemodialisis di RSU Dokter Soedarso Pontianak. Universitas Tanjungpura. https://doi.org/10.1145/3132847.3132886

Garini, A. (2018). Kadar Hemoglobin Pada Pasien Gagal Ginjal Kronik Yang Menjalani Hemodialisis. JPP (Jurnal Kesehatan Poltekkes Palembang), 13(2), 111-116. https://doi.org/10.36086/jpp.v13i2.234

Guerrero-García, C., \& Rubio-Guerra, A. F. (2018). Combination therapy in the treatment of hypertension. Drugs in Context, 7, 1-9. https://doi.org/10.7573/dic.212531 Guidelines. (2020). Hypertension Diagnosis and Management.

Herzog, C. A., Asinger, R. W., Berger, A. K., Charytan, D. M., Díez, J., Hart, R. G., Eckardt, K. U.,

Kasiske, B. L., McCullough, P. A., Passman, R. S., Deloach, S. S., Pun, P. H., \& Ritz, E. (2011). Cardiovascular disease in chronic kidney disease. A clinical update from Kidney Disease: Improving Global Outcomes (KDIGO). Kidney International, 80(6), 572-586. https://doi.org/10.1038/ki.2011.223

Hill, Nathan R. Fatoba, Samuel T. Jennifer A. Hirst1, C., \& A. O'Callaghan, Daniel S. Lasserson, F. D. R.H. (2009). Prevalence of chronic kidney disease: A systematic review and meta-analysis. Clinical Nephrology, 71(3), 244-254. https://doi.org/10.5414/CNP71244

Husna, N., \& Larasati, N. (2019). Evaluasi Penggunaan Terapi Antihipertensi Pada Pasien Gagal Ginjal Kronik Dengan Hemodialisis. Media Ilmu Kesehatan, 8(1), 1-8. https://doi.org/10.30989/mik.v8i1.249

Hutagaol, E. V. (2017). Peningkatan Kualitas Hidup pada Penderita Gagal Ginjal Kronik yang Menjalani Terapi Hemodialisa Melalui Psychological Intervention di Unit Hemodialisa RS Royal Medan tahun 2016. Jurnal JUMANTIK, 2(1), 42-59. https://doi.org/10.1080/13507486.2015.1047603

IRR. (2014). Report Of Indonesia Renal Registry. Clinical Journal of the American Society of Nephrology, 1-36. https://doi.org/10.2215/CJN.02370316

IRR. (2017). 10 th Report Of Indonesian Renal Registry 2016. 1-46. IRR. (2018). 11th Report Of Indonesian Renal Registry 2018. Irr, 1-46. https://www.indonesianrenalregistry.org/data/IRR 2018.pdf JNC. (2014). JNC 8 Hypertension Guideline Algorithm. 311(5).

Kamaliah, N. I. Al, Cahaya, N., \& Rahmah, S. (2021). Gambaran Karakteristik Pasien Gagal Ginjal Kronik Yang Menggunakan Suplemen Kalsium di Poliklinik Sub Spesialis Ginjal Hipertensi Rawat Jalan RSUD Ulin Banjarmasin. Jurnal Pharmascience, 8(1), 111. https://doi.org/10.20527/jps.v8i1.8599

Kandarini, Y. (2017). Tatalaksana Farmakologi Terapi Hipertensi. Divisi Ginjal Dan Hipertensi RSUP Sanglah Denpasar.

Kario, K., Tomitani, N., Kanegae, H., Ishii, H., Uchiyama, K., Yamagiwa, K., Shiraiwa, T., Katsuya, T., Yoshida, T., Kanda, K., Hasegawa, S., \& Hoshide, S. (2017). Comparative effects of an Angiotensin II Receptor Blocker (ARB)/Diuretic vs. ARB/calcium-channel blocker combination on uncontrolled nocturnal hypertension evaluated by information and communication technology-based nocturnal home blood pressure monitorin. Circulation Journal, 81(7), 948-957. https://doi.org/10.1253/circj.CJ- 170109

Katzung, B. G., Masters, S. B., \& Trevor, A. J. (2013). Farmakologi Dasar \& Klinik Edisi 12. In Buku Kedokteran EGC, Jakarta. (12th ed., Issue 9). McGraw-Hill Medical. 
KDIGO. (2013). Chapter 1: Definition and classification of CKD. Kidney International Supplements, 3(1), 19-62. https://doi.org/10.1038/kisup.2012.64

KDIGO. (2017). The interpretation of KDIGO 2017 clinical practice guideline update for the diagnosis, evaluation, prevention and treatment of chronic kidney disease-mineral and bone disorder (CKDMBD). Chinese Journal of Evidence-Based Medicine, 17(8), 869-875. https://doi.org/10.7507/16722531.201708015

KDIGO. (2021). KDIGO 2021 Clinical Practice Guideline for the Management of Blood Pressure in Chronic Kidney Disease. Kidney International, 99(3), S1-S87. https://doi.org/10.1016/j.kint.2020.11.003

Kemenkes. (2016). Anatomi Fisiologi Manusia (A. S. Raimudus Chalik, Ida Malati Sadjati, Sunarti (ed.)). Pusdik SDM Kesehatan, Badan Pengembangan dan Pemberdayaan Sumber Daya Manusia Kesehatan. https://ejournal.poltektegal.ac.id/index.php/siklus/article/view/298\%0Ahttp://repositorio.unan.edu.ni/2 986/1/5624.pdf\%0Ahttp://dx.doi.org/10.1016/j.jana.2015.10.005\%0Ahttp://www.biomedcentral.com/ 1471-2458/12/58\%0Ahttp://ovidsp.ovid.com/ovidweb.cgi?T=JS\&P

Kementrian kesehatan RI. (2017a). Anatomi Fisiologi. Kementrian Kesehatan Republik Indonesia. Kementrian kesehatan RI. (2017b). Petunjuk Teknis Evaluasi Penggunaan Obat Di Fasilitas Kesehatan. Kementerian Kesehatan Republik Indonesia, 1-50.

Kepada, D., Ilmu, F., Universitas, K., \& Mataram, M. (2019). Diajukan Kepada Fakultas Ilmu Kesehatan Universitas Muhammadiyah Mataram Sebagai Syarat Memperoleh Gelar Ahli Madya Farmasi”.

Kudo, D., Yoshida, Y., \& Kushimoto, S. (2017). Permissive hypotension/hypotensive resuscitation and restricted/controlled resuscitation in patients with severe trauma. Journal of Intensive Care, 5(1), 1-8. https://doi.org/10.1186/s40560-016-0202-z

Lee, Y. Bin, Lee, J. S., Hong, S. hyeon, Kim, J. A., Roh, E., Yoo, H. J., Baik, S. H., \& Choi, K. M. (2021).Optimal blood pressure for patients with chronic kidney disease: a nationwide population-based cohort study. Scientific Reports, 11(1), 1-8. https://doi.org/10.1038/s41598-021-81328-y

Levey, A. S., Schoolwerth, A. C., Burrows, N. R., Williams, D. E., Stith, K. R., \& McClellan, W. (2009). Comprehensive Public Health Strategies for Preventing the Development, Progression, and Complications of CKD: Report of an Expert Panel Convened by the Centers for Disease Control and Prevention. American Journal of Kidney Diseases, 53(3), 522-535. https://doi.org/10.1053/j.ajkd.2008.11.019

Lloyd-Jones, D. M., Morris, P. B., Ballantyne, C. M., Birtcher, K. K., Daly, D. D., DePalma, S. M., Minissian, M. B., Orringer, C. E., \& Smith, S. C. (2017). 2017 Focused Update of the 2016 ACC Expert Consensus Decision Pathway on the Role of Non-Statin Therapies for LDL-Cholesterol Lowering in the Management of Atherosclerotic Cardiovascular Disease Risk: A Report of the American College of Cardiology Task Fo. Journal of the American College of Cardiology, 70(14), 1785-1822. https://doi.org/10.1016/j.jacc.2017.07.745

Lubis, A. R., Tarigan, R. R., Nasution, B. R., Ramadani, S., \& Vegas, A. (2016). Pedoman penatalaksanaan gagal ginjal kronik. Divisi Nefrologi- Hipertensi Departemen Ilmu Penyakit Dalam, 1-31.

Lukela, J. R., Harrison, R. V., Jimbo, M., Mahallati, A., Saran, R., \& Annie, Z. (2019). Management of Chronic Kidney Disease Key points. UMHS Chronic Kidney Disease Guideline, July, 1-27.

Luyckx, V. A., Stanifer, J. W., \& Tonelli, M. (2018). World Health Organization. Global Burden Of Kidney Disea. Bulletin of the World Health Organization, March, 414-422. https://www.who.int/bulletin/volumes/96/6/17-206441-ab/es/

Lydia, A., \& Pringgodigdo, N. (2018). Kondisi kesehatan ginjal masyarakat Indonesia dan perkembangannya. Perhimpunan Nefrologi Indonesia, 1-25.

Mancia, G., Fagard, R., Narkiewicz, K., Redon, J., Zanchetti, A., Böhm, M., Christiaens, T., Cifkova, R., De Backer, G., Dominiczak, A., Galderisi, M., Grobbee, D. E., Jaarsma, T., Kirchhof, P., Kjeldsen, S. E., Laurent, S., Manolis, A. J., Nilsson, P. M., Ruilope, L. M., ... Wood, D. A. (2013). ESC Hypertension Guidelines for The Management of Arterial Hypertension. European Heart Journal,34(28), 2159-2219. https://doi.org/10.1093/eurheartj/eht151

Matzke, G. R., Aronoff, G. R., Atkinson, A. J., Bennett, W. M., Decker, B. S., Eckardt, K. U., Golper, T., Grabe, D. W., Kasiske, B., Keller, F., Kielstein, J. T., Mehta, R., Mueller, B. A., Pasko, D. A., Schaefer, F., Sica, D. A., Inker, L. A., Umans, J. G., \& Murray, P. (2011). Drug dosing consideration in 
patients with acute and chronic kidney diseasea clinical update from Kidney Disease: Improving Global Outcomes (KDIGO). Kidney International, 80(11), 1122-1137. https://doi.org/10.1038/ki.2011.322

McPhee, S. J., \& Ganong, W. F. (2007). Fisiopatología médica: introducción a la medicina clínica (p.754). Menkes, R. (2011). Modul penggunaan obat rasional. Kementerian Kesehatan RI, 1-192.

Muchtar, N. R., Tjitrosantoso, H., \& Bodhi, W. (2015). Studi Penggunaan Obat Antihipertensi Pada Pasien Gagal Ginjal Kronik Yang Menjalani Perawatan Di Rsup Prof. Dr. R. D. Kandou Manado Periode Juli 2013 - Juni 2014. Jurnal Ilmiah Farmasi, 4(3), 22-28. https://doi.org/10.35799/pha.4.2015.8833

Muhadi. (2016). JNC 8 : Evidence-based Guideline Penanganan Pasien Hipertensi Dewasa. Cermin Dunia Kedokteran, 43(1), 54-59.

Muti, A. F., \& Chasanah, U. (2016). Evaluasi Rasionalitas Penggunaan Diuretic pada Pasien Gagal Ginjal Kronik yang Dirawat Inap di RSUD Dr. Saiful Anwar Malang. Sainstech Farma, 9(2), 23-31.

Nathional Health Service. (2012). Enfermedad Renal Crónica en Inglaterra. 44. https://www.england.nhs.uk/improvement-hub/wp-content/uploads/sites/44/2017/11/Chronic-KidneyDisease-in-England-The-Human-and-Financial-Cost.pdf

Ndraha, Suzanna. Jean Nadya PR, Marshell Tendean, M. S. (2018). Gambaran Penyakit Ginjal Kronik dan Komplikasinya di RSUD Koja Periode Juli-November 2017. 24(67), 1-4.

PERNEFRI. (2020). Integreted Collaboration for Excellent Kidney Care.

Pradningsih, A., Nopitasari, B. L., Nurbaety, B., \& Zuhroh, H. (2020). Evaluasi Penggunaan Obat Antihipertensi pada Pasien Gagal Jantung Rawat Jalan di Rumah Sakit Umum Daerah Provinsi Nusa Tenggara Barat. Lumbung Farmasi: Jurnal Ilmu Kefarmasian, 1(2), 66. https://doi.org/10.31764/lf.v1i2.2542

Pranandari, R., \& Supadmi, W. (2015). Faktor Risiko Gagal Ginjal Kronik di Unit Hemodialisis RSUD wates Kulon Progo. Majalah Farmaseutik, 11(2), 316-320. https://doi.org/10.1063/1.1655531

Prastiwi, A. D., \& Wibowo, W. A. (2009). Efusi Pleura Eksudatif pada Pasien Gagal Ginjal Kronis yang Menjalani Hemodialisa Rutin. https://publikasiilmiah.ums.ac.id/xmlui/handle/11617/11239

Price, S. A., \& Wilson, L. M. (2012). Patofisiologi Konsep Klinis Proses-Proses Penyakit (D. A. M. Huriawati Hartanto, Natalia Susi, Pita Wulansari (ed.); 6th ed.).

Pugh, D., Gallacher, P. J., \& Dhaun, N. (2019). Management of Hypertension in Chronic Kidney Disease. Drugs, 79(4), 365-379. https://doi.org/10.1007/s40265-019-1064-1 RISKESDAS. (2013a). Penyajian Pokok-Pokok Hasil Riset Kesehatan Dasar 2013.

RISKESDAS. (2013b). Riset Kesehatan Dasar. In Trihono (Ed.), Badan Penelitian dan Pengembangan Kesehatan Kementrian Kesehatan RI. Menteri Kesehatan Republik Indonesia. https://doi.org/10.1517/13543784.7.5.803

Rivandi, J., \& Yonata, A. (2015). Hubungan Diabetes Melitus Dengan Kejadian Gagal Ginjal Kronik. Jurnal Majority, 4(9), 27-34. http://juke.kedokteran.unila.ac.id/index.php/majority/article/view/1404/1246

Ruebner, R. L., \& Pradhan, M. (2018). Chronic kidney disease. The 5-Minute Pediatric Consult, 8th Edition, May, 194-195.

Sa'idah, D., Sugihantoro, H., Hakim, A., \& Maimunah, S. (2019). Evaluasi Rasionalitas Penggunaan Obat Antihipertensi di Instalasi Rawat Jalan RSUD dr. Soegiri Lamongan Periode Tahun 2017. Jurnal Ilmu Kefarmasian Indonesia, 17(1), 107. https://doi.org/10.35814/jifi.v17i1.650

Sagita, Tiffany Christine. Andreas Arie Setiawan, H. (2018). Hubungan Derajat Keparahan Gagal Ginjal Kronik Dengan Kejadian Penyakit Jantung Koroner. Diponegoro Medical Journal (Jurnal Kedokteran Diponegoro), 7(2), 472-484.

Salwa, A. (2013). Evaluasi Penggunaan Obat Antihipertensi pada Pasien Hipertensi dengan Gagal Ginjal di Instalasi Rawat Inap RS “ X” tahun 2010. Fakultas Farmasi Universitas Muhammadiyah Surakarta.

Saran, R., Robinson, B., Abbott, K. C., Bragg-Gresham, J., Chen, X., Gipson, D., Gu, H., Hirth, R. A., Hutton, D., Jin, Y., Kapke, A., Kurtz, V., Li, Y., McCullough, K., Modi, Z., Morgenstern, H., Mukhopadhyay, P., Pearson, J., Pisoni, R., ... Shahinian, V. (2020). US Renal Data System 2019 Annual Data Report: Epidemiology of Kidney Disease in the United States. American Journal of Kidney Diseases, 75(1), A6-A7. https://doi.org/10.1053/j.ajkd.2019.09.003

Sarwana, S. (2016). Hubungan penyakit ginjal kronik dengan anemia pada pasien rawat inap RSUD Bari Palembang tahun 2014. 52. 
Sastroasmoro, S. (2011). Dasar-dasar metodologi penelitian klinis. Sagung seto.

Senduk, C. R., Palar, S., \& Rotty, L. W. A. (2016). Hubungan anemia dengan kualitas hidup pasien penyakit ginjal kronik yang sedang menjalani hemodialisis reguler. E-CliniC, 4(1). https://doi.org/10.35790/ec1.4.1.2016.10941

Sinaga, C. R. H. T. F. (2017). Evaluasi Kerasionalan Penggunaan Antibiotik Pada Pasien Gagal Ginjal Di Rsup Prof. Dr. R. D. Kandou Manado. Pharmacon, 6(3), 10-19. https://doi.org/10.35799/pha.6.2017.16512

Sinha, A. D., \& Agarwal, R. (2019). Clinical pharmacology of antihypertensive therapy for the treatment of hypertension in CKD. Clinical Journal of the American Society of Nephrology, 14(5), 757-764. https://doi.org/10.2215/CJN.04330418

Sirait, F. R. H. M. I. sari. (2017). Ensefalopati Uremikum pada Gagal Ginjal Kronis Uremic Encephalophaty in Chronic Kidney Disease. Jurnal Medula, 7, 19-24. http://repository.lppm.unila.ac.id/5039/1/J Medula UnilaVolume 7Nomor 1Januari 2017.pdf

Smith, D. K., Lennon, R. P., \& Carlsgaard, P. B. (2020). Managing Hypertension Using Combination Therapy. American Family Physician, 101(6), 341-349.

Sukandar, E. Y. (2011). Iso Farmakoterapi. Ikatan Apoteker Indonesia.

Tamsil, Y., Moeis, E. S., \& Wantania, F. (2020). Gambaran Anemia pada Subjek Penyakit Ginjal Kronik Stadium 4 dan 5 di Poliklinik Ginjal-Hipertensi RSUP Prof. Dr. R. D. Kandou. E-CliniC, 8(1), 60-66. https://doi.org/10.35790/ec1.8.1.2020.27097

Tandi, M., Mongan, A., \& Manoppo, F. (2014). Hubungan Antara Derajat Penyakit Ginjal Kronik Dengan Nilai Agregasi Trombosit Di Rsup Prof. Dr. R. D. Kandou Manado. Jurnal E-Biomedik, 2(2). https://doi.org/10.35790/ebm.2.2.2014.5076

Tortora, G. J. (2011). Principles of Anatomi and Physiologi. Wiley. https://books.google.co.id/books?id=uNwfOPPYgKAC \&printsec=frontcover\#v=onepage \&q\&f=false

Triastuti, I. (2017). A cute kidney injury (AKI). Universitas Udayana. https://doi.org/10.1007/978-3-64254859-8_13

Tripathi, K. (2013). Medical Pharmacology seventh edition. In Bmj (7th ed., Vol. 2, Issue 5260). https://doi.org/10.1136/bmj.2.5260.1131

Tuloli, T. S., Madania, Adam, M. M., \& Tuli, E. P. (2019). Evaluasi penggunaan obat pada pasien gagal ginjal kronik yang menjalani hemodialisis di Rsud Toto Kabila periode 2017-2018. Parapemikir: Jurnal Ilmiah Farmasi, 8(2), 25-32.

Unger, T., Borghi, C., Charchar, F., Khan, N. A., Poulter, N. R., Prabhakaran, D., Ramirez, A., Schlaich, M., Stergiou, G. S., Tomaszewski, M., Wainford, R. D., Williams, B., \& Schutte, A. E. (2020). 2020 International Society of Hypertension Global Hypertension Practice Guidelines. Hypertension, 75(6), 1334-1357. https://doi.org/10.1161/HYPERTENSIONAHA.120.15026

Velasquez, M. T. (2015). Management of Hypertension in Chronic Kidney Disease. In Chronic Renal Disease. Elsevier Inc. https://doi.org/10.1016/B978-0-12-411602-3.00052-4

Weber, M. A., Schiffrin, E. L., White, W. B., Mann, S., Lindholm, L. H., Kenerson, J. G., Flack, J. M., Carter, B. L., Materson, B. J., Ram, C. V. S., Cohen, D. L., Cadet, J. C., Jean-Charles, R. R., Taler, S., Kountz, D., Townsend, R. R., Chalmers, J., Ramirez, A. J., Bakris, G. L., ... Harrap, S. B. (2014). Clinical Practice Guidelines for the Management of Hypertension in the Community: A Statement by the American Society of Hypertension and the International Society of Hypertension Clinical Practice Guidelines for the Management of Hypertension in the Comm. Journal of Clinical Hypertension, 16(1), 14-26. https://doi.org/10.1111/jch.12237

Wells, Barbara G., DiPiro, J. T., Schwinghammer, T. L., \& DiPiro, C. V. (2015). Pharmacotherapy Handbook (9th ed.). McGraw-Hill Education. https://doi.org/10.2514/6.2010-8193

Wells, Barbbara G., DiPiro, J. T., Schwinghammer, T. L., \& DiPiro, C. V. (2009). PharmacotherapyHandbook. In The Annals of Pharmacotherapy (7th ed.). McGraw-Hill Companies, Inc. https://doi.org/10.1345/aph.10237

Wibawa, P. P. (2016). Ginjal dan urine. Diktat Biokimia, 1-33. https://simdos.unud.ac.id/uploads/file_pendidikan_1_dir/bbaf9351825f25035476868944b4f17f.pdf

Yusman, F. A., Dewi, R. T. K., Mashuri, Y. A., Nurhayatun, E., \& Giani, M. T. (2020). Faktor yang Berkaitan dengan Kejadian Asites pada Pasien Penyakit Ginjal Kronik yang Menjalani Hemodialisis di 


\section{Jurnal Mitra Kesehatan (JMK)}

DOI: $10.47522 /$ jmk.v1iIAHSC.123

RSUD Dr Moewardi Surakarta: Sebuah Studi Potong Lintang. Jurnal Penyakit Dalam Indonesia, 7(3), 154. https://doi.org/10.7454/jpdi.v7i3.420

Zhang, Q. L., \& Rothenbacher, D. (2008). Prevalence of chronic kidney disease in population-based studies: Systematic review. BMC Public Health, 8. https://doi.org/10.1186/1471-2458-8-117 